\title{
Cultural Capital as the Condition and Factor for the Development of the Economy and Cultural Policy in the Region
}

\author{
Galina M. Kazakova \\ and Anastasia Yu. Ryazanova* \\ Chelyabinsk State Institute of Culture and Arts \\ 36 a Ordzhonikidze Str., Chelyabinsk, 454091, Russia
}

Received 19.10.2017, received in revised form 24.01.2018, accepted 08.02.2018

The article describes the modern culture industry as a special mechanism in cultural policy, which will increase the symbolic capital of the territory. A distinction is made between the concepts of 'culture industry', 'cultural industry' and 'cultural capital'. The article considers the issues of involvement of the culture industry and cultural capital of the population in the economy of the region. It is explained that the sphere of culture can be represented as a cultural capital with a certain potential for regional development.

Keywords: regional economy, sphere of culture, cultural capital, culture industry.

DOI: 10.17516/1997-1370-0218.

Research area: culturology.

In modern society, culture is an integral part, an instrument of economic development. Already in 1982, UNESCO defining the notion of 'culture', outlined this new role to be played in the modern world: "a set of characteristic features, material and spiritual, logical and sensual, that characterize society or a social group. In a broad sense, the concept of culture combines art and literature, various styles of life, basic human rights, a system of values, traditions and beliefs" (Moulinier, 2002).

Today the issue of regional cultural policy requires a comprehensive, conceptual study. It has already become obvious that culture can be viewed both as a product and as a resource that, while playing the role of a lever of economic development, form the competitive advantages of the territory (Kopatskaya, 2017: 80). In applied cultural studies, this problem is the most urgent. It is not just about the issues of cultural policy, but also about the development of new principles, mechanisms and methods of cultural development, the construction of new forms of cultural practices. Interpretation of the sphere of culture as a resource potential of the region is capable of giving new priorities in understanding its purpose and capabilities, marked not only by preserving the cultural and historical heritage. Cultural resources, like any other type of resource, subject to certain conditions, can bring

(C) Siberian Federal University. All rights reserved

* Corresponding author E-mail address: rritayu@yandex.ru 
'profit' (increase in GRP and tax deductions to the budget, etc.) (Fedotova, 2011: 18). Culture can act as a powerful regional resource capable of giving a new impetus to the provincial territory, to become the foundation of its development. In the mid-1990s, serious research in the sphere of culture began in Europe to study the process by which culture becomes a certain kind of capital, the engine of economic growth. Scientists on numerous examples have shown that culture can be considered as a strategic factor of social and economic changes. Studying the potential of the region's culture sector and its ability to feed and stabilize various types of economic activity, experts concluded that culture, with certain financial investments, can have the properties of a catalyst for regional changes (Fedotova, 2013: 19). Such resources include: 'cultural industries', 'cultural capital' and 'cultural industry'. The semantic content of these concepts is 'mobile' and creates a situation of interchangeability of terms, which complicates understanding of the specificity of the phenomena they designate, and also reduces the effectiveness of cultural policies. Let us give some distinction of these three concepts.

As a rule, the word combination 'cultural industries' means art production (including design) implemented by mass replication (Horkheimer, Adorno, 1997). Cultural industries are the production of directly cultural or substantially culturally regulated phenomena that are more or less massive in scope and highly standardized in most of their characteristics. This is a system of cultural practices that are implemented not in the innovative-search (creative) mode, but in accordance with the standards that implement the most relevant technologies of social production and the parameters of products created in this case. It is these signs - mass character and standardizationthat distinguish cultural industries from another mode of cultural production - cultural creativity, which has the typical features of innovation, uniqueness, author's originality and, as a rule, high quality (Flier, 2012). That is, the current understanding of the social role of culture made it possible to define the place of the cultural industry as a link connecting artistic values and real life. Culture becomes the foundation of social and economic development, thus actualizing its social significance and role in the social reconstruction.

Theorists of the Frankfurt School T. Adorno and M. Horkheimer introduced the term 'culture industry' in the work "Dialectic of Enlightenment" (Adorno, Horkheimer, 1997). The authors interpret the culture industry as a phenomenon of the formation of a new mode of culture production, which turns into one of the branches of the economy (Khangeldiyeva, 2010 :24). In their opinion, the culture industry is an entire industrial apparatus for the production of uniform, standardized novelties in the spheres of art, painting, literature, cinema, etc. It does not offer any value guidelines for man, is not aimed at spiritual enrichment and enlightenment, being actually an entertainment business. The culture industry is understood as a variety of goods, which has a producer and a consumer (Adorno, Horkheimer, 1997).

The term 'cultural capital' differs greatly from these terms. If the two above terms refer to the 'external sphere' of society as a whole, 'cultural capital' is manifested through the formation of an individual through education. The theoretical concept of 'cultural capital' was introduced by the French sociologist P. Bourdieu (Bourdieu, 2005). Considering the ability of cultural capital to convert into economic one, he distinguished three states of cultural capital: incorporate - in the form of long dispositions of the mind and body (language, culture, traditions); objectified in the form of cultural goods (paintings, books, dictionaries, instruments, machines, etc.); 
institutionalized - in the form of academic qualifications. The concept of cultural capital is used not only to characterize the individual, but also different types of communities (Antonova, 2012: 62). Unlike P. Bourdieu, D. Trosby's concept of cultural capital implied a market approach to this phenomenon. He attributed to cultural capital all the artifacts and cultural phenomena that may have a market value. Starting in the 1970s with the study of the problems of the economy of culture, D. Trosby created an integral concept of cultural capital, to which he also classified the cultural heritage, while noting that "the material cultural capital inherited from the past can be regarded as something close to natural resources that have also been given us as an inheritance" (Trosby, 2013: 155).

At the same time, the goal of the culture industry is the creation of a commercial product. The goal of cultural industries is the creation of an artistic product of symbolic value. Cultural capital is the spiritual, aesthetic and intellectual heritage of the region, which possesses the capabilities and opportunities to create a unique product.

Thus, cultural capital is the first level. It combines the achievements of the era and the creative abilities of man, forming a 'new cultural product'. The next level is the cultural industries, they turn the 'cultural product' of cultural capital into a cultural value, i.e. is of a massive nature (it creates a 'breeding ground' for creativity). But, this level is the core of cultural capital. And the last level is the culture industries as an economic branch. As a result, through the interaction of all three levels, external changes are revealed (material growth (development of cities), surplus value of a cultural product, symbolic-spiritual and artistic growth, labour and economic growth) and internal changes (man himself as a person and man as a representative of the humankind in the era).
After considering the 'theory' according to these terms, one can go directly to 'practice'. In the context of the analysis of these concepts in the cultural policy of the region, we draw attention to the issues of contemporary cultural production and consumption. It has long been known that the sphere of culture, like any other industry, can contribute to the development of the region. Thus, G. Tulchinsky (Tulchinsky, 2009: 122). distinguishes several levels of the role (contribution) of culture and art in the development of modern society:

(a) Direct contribution of the sphere of culture to the economy (creating new jobs, directly contributing to the development of the economy of a particular region, culture and art are the main source of development of education, media, tourism and entertainment);

(b) Direct social influence (culture and art provide socially important activities, recreation, positively influence the consciousness of people, the relationship between them, contribute to the spiritual development of the individual and society as a whole, the disclosure of their creativity);

(c) Indirect economic influence (culture and art translate certain basic values of society, increase the value of the environment);

(d) Indirect social influence (culture and art enrich the social environment, increase the degree of socialization of the individual, they are the source of civilizational influence and social organization).

Cultural resources, like any other type of resource, subject to certain conditions, can bring 'profit' (Fedotova, 2013: 20). In this respect, cultural resources are often considered in the context of the very popular concept of 'cultural capital'. In the economic theory, interpretations of cultural capital world are limited to understanding of it as one of many other capitals - human, material, natural. 
Capitalization of cultural resources is nothing but a successful fulfillment of the cultural potential in a particular region. As a result, an environment is formed that promotes the development of creative forces bringing economic and aesthetic 'profit', harmonizing the social climate in the region, feeding the social forces of the region. In recent years, "new benchmarks have emerged in the activity of the cultural institutions: the solution of social problems, the development of social communication and stimulation of creativity attracting investment and increasing the competitiveness of the region" (Gnedovsky, 2008: 4). Competent culture management involves the formation of a dialogue between business, cultural elite and authorities, revival of fundraising mechanisms.

Fundraising is a process of searching for and attracting financial and material resources carried out by managers of non-profit organizations (Rubinshtein, 2005: 506).

As an example, the Lincoln Center's experience of one of the popular forms of working with sponsors is the sale by cultural organizations of so-called nominal places, where for a certain amount of money you can get the right to place your name. This can be an inscription on the wall ('donor walls'), a column, a pedestal, etc. Thus, the Metropolitan Museum in New York, the largest art museum in the US, sold 5,000 roofing tiles for $\$ 500$ each, on which could be engraved the names of the sponsors. In Russia, for example, the Hermitage, the Tretyakov Gallery, Tovstonogov Bolshoi Drama Theater, the Bolshoi and Mariinsky theaters clearly show the tendency of growth of attracted sources of financing through fundraising. Thus, the German company Escada in 2003 organized a show of its collection at the Bolshoi Theater in TrubetskoyBova in Petrovsky Lane. Cooperation with the Bolshoi Theater continued in the next season. This time the press-show of a new, autumn- winter collection took place in the ballet class of the Auxiliary Building of the Bolshoi Theater (Ministry of Culture).

In the sphere of culture there are many gaps for the development of the commercial sector, the implementation of successful business projects, the development of entrepreneurship (Fedotova, 2013: 25). Let us consider successful cultural projects involving extrabudgetary funds (public-private partnership (Abankina, 2010: 5): International Street Theater Festival "Dreams of the streets" in Tyumen, International Festival of Cinematographic Debuts "Spirit of Fire", All-Russian Exhibition "Posters of War. On the way to the Great Victory in Chelyabinsk, etc. (Ministry of Culture).

The support of the regional authorities for the development of cultural industries can favourably affect the socio-cultural and economic situation in the regions.

Firstly, as a result of supporting the production of cultural industries, the urban environment is being formed.

Secondly, the established interaction of creativity and commerce opens the way for the modernization of cultural institutions (cultural institutions are experiencing a period of adaptation to market conditions, which stimulates them to search for innovative forms of selling their own resources).

Thirdly, the capitalization of culture creates the conditions for increasing the regional potential of the creative economy, the knowledge economy, which is a serious alternative to the raw material economy. Defining creative industries as a priority for economic development, they turn this sector into a significant source of income (Fedotova, 2013: 29).

Fourth, it contributes to the construction of regional identity. Symbolic management is widely used to create a positive image of the region, intended for external and internal audiences - 
'buyers'. The development of the programmes of symbolic management takes place in the traditions of economic science: marketing, branding, the economic theory of image and other disciplines. The benefit from the introduction of symbolic programmes is assessed in terms of increasing the investment attractiveness of the territory and, as a result, its economic growth (Gnedovsky).

All this leads to the overall result, working in general for the region: infrastructure development, employment and jobs for young people, the opportunity to implement creative initiatives without concern for material prosperity, the influx of tourists, the design of the urban environment and public space, the upgrading of territories, the lease of empty plants and factories. For example, Liverpool, Manchester or Sheffield, known for their industrial potential, have become a place where industrial neighbourhoods have become creative clusters. In certain areas of the city, places were created where many independent small creative companies were located, an attractive creative environment and atmosphere was created with the cooperation and interaction between different structures. The development of creative clusters caused a complex positive fluence, stimulated the rise of the innovative sector of the economy (for example, multimedia processing of creative products), created additional jobs, substantially transformed the urban environment, and also caused other socio-cultural and economic consequences.

Capitalization of culture in Russia can be associated not only with the solution of sociocultural or economic problems, but also with the creation of conditions for increasing the competitiveness of cities and regions. However, today Russia is far from being a laboratory for the introduction of creative potential into a creative product, despite the richest cultural resources of the regions. The share of major copyrightbased industries, that is, the core of the creative industries, in Russia's export is only $0.49 \%$ (compared with $18.29 \%$ in China, $8.35 \%$ in Italy, $7.61 \%$ in the US, $5.67 \%$ in the UK). At the moment, creative clusters are actively developing in Moscow and St. Petersburg, which in general are very similar to each other and represent art centers related to activities in the field of contemporary art. The most popular among them are the Moscow Center for Contemporary Art 'Winzavod', the capital's creative cluster 'FabRika', the Center for Contemporary Culture 'Garage', the design center 'Artplay' (Fedotova, 2013).

Thus, a culture filled with new content and new ways of experiencing can and should interact with the region and 'work' for it. Today, the culture industries in the territories, have the potential to solve the numerous social, cultural and economic problems of the regions.

\section{Reference}

Abankina, T.V. (2010). The development of public-private partnership in the sphere of culture, In Directory of the head of the institution of culture. 2, 5-17.

Antonova, M.A. (2012). Cultural capital of the region's population, In Problems of territory development. 2, 62-69.

Bourdieu, P. Radaev, V.V. (2005). Forms of Capital, trans. M.S. Dobryakova; sci. Ed., In Economic Sociology. 6(3), 60-74.

Gnedovsky, V.M, Averchenkova, S.V, Gnedovsky, M.B. (2008). Capitalizing the genius of the place and the spirit of the time: Stratford-upon-Avon - Weimar - Yasnaya Polyana, In Cultural heritage as a factor of sustainable regional development. 4. 
Kazakova, G.M, Ryazanova, A.Yu. (2017). Formation of regional identity as a driver of economic development of the region and the city, In Urbanistics. 3. DOI: 10.7256 / 2310-8673.0.0.22480. Available at: http://e-notabene.ru/urb/article_22480.html

Kopatskaya, S.A. (2009). Regionalization of cultural policy as one of the approaches to managing the cultural potential of territories, In Almanac of Modern Science and Education. 3(22), 80-88.

Ministry of Culture of the Russian Federation. Available at: http://mkrf.ru/ministerstvo/ management/minister/.

Rubinshtein, A.Ya. (2005). Economics of Culture: Textbook for universities, 608 p.

Trosby, D. (2013). Economics and Culture, $256 \mathrm{p}$.

Tulchinsky, G.L. (2009). Management in the field of culture, 384 p.

Fedotova, N.G. (2013). Vectors of regional cultural policy in the field of capitalization of culture, In Proceedings of the St. Petersburg State University of Culture and Arts. 199, 17-32.

Fedotova, N.G. (2011). The sphere of culture as a strategic resource of the region. In Bulletin of the Novgorod State University. 63, 17-21.

Flier, A.Ya. (2012). Cultural industries in history and modernity: types and technologies, In Informational humanitarian portal "Knowledge. Understanding. Skill". 3 (May-June). Available at: http://zpu-journal.ru/e-zpu/2012/3/Flier_Cultural-Industries/ (date of circulation: 03.04.17)

Khangeldiyeva, I.G. (2010). Pros and cons of the commercialization of culture and art, In Applied Culturology: KALEIDOSCOPE IDEAS, $400 \mathrm{p}$.

Horkheimer, M., Adorno, T. (1997). Dialectics, of Enlightenment: Philosophical Fragments. M.: Medium; St. Petersburg.

Moulinier P. (2002). Politique culturelle et décentralisation. Paris: l'Harmattan, 338 p.

\section{Культурный капитал как условие и фактор развития экономики}

\section{и культурной политики региона}

Г.М. Казакова, А.Ю. Рязанова

Челябинский государственный институт культуры Россия, 454091, Челябинск, ул. Орджсникидзе, $36 а$

В статье дается характеристика современной индустрии культуры как особого механизма в культурной политике, который позволят увеличивать символический капитал территории. Разграничиваются понятия «индустрия культурыл", «культурная индустрия» и «культурный капитал». Рассматриваются вопросы вовлеченности индустрии культуры и культурного капитала населения в экономику региона. Дается объяснение, что сфера культуры может быть представлена как культурный капитал, обладающий определенным потенщиалом для регионального развития.

Ключевые слова: экономика региона, сфера культуры, культурный капитал, индустрия культуры.

Научная специальность: 24.00.00 - культурология. 